\title{
평화활동의 주변에서 지속적 평화의 중추로: 평화구축과 평화의 지속화를 위한 시민사회의 역할론을 중심으로
}

목차

I. 서론

II. UN 평화의제의 발전과 시민사회

1. UN 평화활동의 전환

2. UN 평화구축의 개념 형성과 진화

3. 평화구축과 지속적 평화의제에서의 시민사회

III. 평화구축 프로세스에 기초한 시민사회의 역할과 쟁점
1. 평화구축활동의 영역
2. 평화구축 프로세스에서 시민사회의 역할
3. 주요 쟁점

IV. 한국 시민사회의 활동 현황과 과제

V. 결론

참고 문헌 


\section{요 약}

본 논문은 지속가능개발목표(Sustainable Development Goals, SDGs) 16과 관련해 국제연합(United Nations, 이하 UN)의 평화의제가 '분쟁 후 평화구축'에서 '평화의 지속화'로 전환되는 과정에서 시민사회의 역할을 살펴보고, 한국의 시민사회에 주는 함의를 조명했다.

$\mathrm{UN}$ 의 평화의제는 초기의 대응적 평화활동에서 냉전 이후의 비국제적 무력 충돌의 확산으로 인해 다면적 평화활동으로 바뀌었다. 이는 평화구축활동이 개념화되고 또 공유되는 계기가 되었으며, 이 과정에서 시민사회가 공공 행위자들로부터 분쟁과 갈등 전환에서의 다양한 역할을 인정받게 되었다. 구체적으로, 평화 프로세스에서 보호·감시. 옹호·내그룹 사회화·응집력 제고·중재·서비스 제공 등의 역할을 해 왔다.

한편, 한국의 개발협력 시민사회가 분쟁-취약국을 대상으로 평화구축과 지속적인 평화 의제를 수행하지 못하고 있다는 분석에 근거해 개발협력 시민사회를 포괄하는 다양한 시민사회와의 연대 구축, 인식 제고와 역량 개발, 컨소시엄형 프로그램 지원, 한반도 평화 프로세스와의 연계 등을 제안했다.

주제어: 평화구축(peacebuiling), 지속적 평화(sustaining peace), 시민사회, 지속가능개발목표 (SDGs), 분쟁·취약국 


\section{I. 서론}

냉전이 종식된 후, 무력 충돌 및 피해자 수는 점차 낮아지는 추세를 보이고 있지만, 비국가적

무력 충돌(non-state armed conflicts)은 여전히 국제 안보에 있어 위협적인 요소로 작용하고

있다. 2017년 기준으로, 전 세계에서 발발한 무력 충돌은 49건이고, 직접 피해로 인한 사망자 수는 69,000명에 달한다(Wallensteen, 2017). 단일국가에서 정부와 교전 무장단체 간, 그리고 연계된 지역사회 간 폭력적인 분열 양태는 궁극적으로 국가 제도의 붕괴를 초래함으로써 화해에 기반한 재건과 평화구축의 과정을 더욱 요원하게 만든다. 특히 무력 충돌을 피해 주거지를 등진 수천만 명의 피난민들은 매순간 삶의 위기에 직면하고 있는 상황이다. 단적인 예로, 지난 10 년간 복합 위기 상황으로 인한 인도적 지원의 요구가 기하급수적으로 증가함에 따라, 국제연합 (United Nations, 이하 UN)의 통합지원호소(Consolidated Appeal Process)의 규모가 235억 달러로 2006 년에 비해 400\% 이상 증가했고, 이러한 기조는 지난 7년간 지속되고 있다(OCHA, 2018). 이처럼 암울한 정황은 국제사회로 하여금 평화에 대한 책무성을 지속적으로 환기시켜 왔다.

2차 세계대전 이후 발생한 무력 충돌에서 평화구축으로 전환하는 데 개입해 온 주요 행위자는 주로 UN과 국민국가였고, 공공 행위자의 관점에서 볼 때 국가 간 무력 충돌에서 시민사회의 참여는 평화구축의 과정을 복잡하게 만드는 불요적인 요소로 인식되었다(Paffenholz, 2001). 그러나 1990년대 이후 무력 충돌의 양상이 복잡하고 다원화됨에 따라, 평화구축에 대한 담론은 “어떤 행위자와 접근 방법이 분쟁을 종식시키고 평화를 구축하는 데 최적의 효과를 나타내는 가?”로 귀결되었다. 이와 관련된 연구들은 대체로 “유엔으로부터 분쟁 당사국의 풀뿌리 조직 혹은 시민사회에 이르는 다수 행위자의 참여와 다양한 접근이 지속적 평화를 가져올 수 있다'는 결론에 도달하게 된다(Reychler and Paffeholz, 2001; Crocker, Hampton, and All, 2001; Paffenholz, 2009).

평화구축 과정에서, 특히 민주화와 거버넌스 구축에 있어 시민사회의 의의와 역할에 대해서는 여타 이해관계자들이 모두 인정하는 사실이다. 하지만, 시민사회의 정체성과 범주 내 행위자의 관점에 대한 보편적이고 합의된 정의가 여전히 부재하다. 이는 평화구축이나 시민사회의 결합 (nexus)과 더불어 시민사회의 순기능과 역기능에 대한 논란을 불러일으키고 있다. 더불어 시민 사회가 참여하는 평화구축활동이 증대하는 만큼 다양한 관점에서 수행되는 연구가 부족한 실정 이다.

한편, 개발협력 관점에서는 인도적 지원이나 개발과 관련한 서비스 전달 기능을 담당하는 
비정부기구(Non-Governmental Organizations, 이하 NGOs)에 대해 평화구축활동의 참여가 내외적으로 요구되었고, 현재 서구의 NGOs는 적극적으로 참여하고 있다. 그러나 이러한 서비스 기반 활동에 최적화된 NGOs가 평화구축에 적합한 행위자인지에 대한 의문은 지속적으로 제기 되고 있다. 다수의 연구가 국제비정부기구(International Non-Governmental Organizations, 이하 INGOs)로 대표되는 외부 시민사회의 무차별적인 개입이 현지 시민사회를 종속화하고 또 그들의 노력을 주변화시킴으로써 유의미한 영향력을 거두지 못한다는 비판적인 시각을 견지 하고 있다(Paffenholz and Spurk, 2006: 27). 이처럼 다차원적인 접근이 요구되는 평화구축의 맥락에서는 시민사회의 포괄적인 범주화가 불가피하다.

본고는 이러한 논의들을 배경으로 우선, UN 체제를 중심으로 평화의제의 형성과 진화를 살펴보고, 그 가운데 시민사회 의의와 역할에 대한 인식적인 변화를 살펴보고자 한다. 그리고 평화구축 프로세스에서 시민사회에게 요구되는 역할과 함께 제기되는 쟁점을 조명하고, 이를 통해 한국의 개발협력 NGOs를 포함한 시민사회에 주는 함의를 도출하고자 한다. 


\section{UN 평화의제의 발전과 시민사회}

2차 세계대전을 계기로 설립된 UN은 헌장을 통해 국제 평화와 안보의 유지를 존립 근거로 천명했고, 분쟁의 예방과 평화를 위협하는 호전적인 행위를 일소하는 데 있어 집단적이면서도 종합적인 대응책을 마련하도록 요구받았다(UN, 1945). 종합적인 대응책이란 사법적 조치와 이에 근거가 되는 국제법의 적용 및 분쟁 당사자 간 조정과 합의 등 분쟁을 평화적으로 해결하기 위한 다양한 노력을 포함하고 있으며, 최후의 보루(last resort)로서 집단안보 체제에 의한 무력 사용을 배제하지 않는 것이다.

그럼에도 미·소 강대국이 주축이 된 냉전 기간 동안 $\mathrm{UN}$ 이 분쟁 방지와 적극적인 개입의 책무를 효과적으로 이행하지 못한다는 비판을 받아 왔다. 이에 보완 기제로서 도입된 군 중심의 제한적인 평화유지활동(peacekeeping operations)은 분쟁 당사국 간 감시를 통해 충돌 가능성을 완화하는 역할을 담당했다.1) 이에 UN은 분쟁의 예방적 노력 이상으로 무력 충돌 발생 시 교전국 간 정전 유도와 평화협약 체결, 평화유지활동으로 연계되는 일련의 평화활동(peace operations)에 중점을 두고 규범적 정의와 정책의 강화, 조직적 개편, 활동과 자원의 확대 등 다양한 조치를 취해 왔다.

따라서 UN 평화구축의제의 진화를 설명하기 위해서는 UN 평화활동의 변화를 초래한 정황 (context)과 이에 대응하기 위한 평화활동의 제도화, 그리고 그 과정에서 평화구축이 어떻게 개념화되고 구체화되었는지 알 수 있다.

\section{UN 평화활동의 전환}

냉전 해체기 이전의 무력 충돌 양상은 4 가지로 구분될 수 있다. 특정 강대국의 세력권 내에서 발생하는 경우, 일부 국가 간 집단 내 문제를 해결하기 위한 결집 사례, 국가 간 국지적인 충돌, 외부 세력의 확대와 적극적 개입으로 인한 확전이다(James, 1990). 당시 상황으로 볼 때, $\mathrm{UN}$ 이 주도하는 대규모 병력 동원은 거의 불가했기 때문에 일시적인 평화협약을 체결한 후 소규모의 평화유지군을 파병해 감시 활동만 가능했다. 그러나 냉전 해체 이후, 강대국에 의한

1) UN에 의해 수행된 평화유지활동의 첫 사례는 1948년 중동에 파견된 유엔정전감시단(United Nations Truce Supervision Organization, UNTSO)과 카슈미르 분쟁에 따른 인도-파키스탄 유엔정전감시단(United Nations Military Observer Group for India and Pakistan, UNMOGIP)이고, 현재까지도 감시 임무를 담당하고 있다. 출처: UN Peacekeeping 홈페이지, “Our History” posted on United Nations Peacekeeping website, available at https://peacekeeping.un.org/en/our-history (접속일: 2018.11.14.). 
힘의 균형이 무너진 상황에서 취약국에 잠재되어 있던 정치적인 압제와 구조적인 불평등, 인종과 종교 간의 갈등, 극심한 빈곤 등의 문제는 비국제적 무력 충돌의 확대를 초래했다(Suhrke and Chaudhary, 2009).

이는 과거와 달리 소말리아, 르완다, 코소보의 사례와 같이 교전 당사자의 인명 피해보다 민간인에 대한 반인도적·반인권적인 잔악 행위로 인한 사상자가 증가하고, 무력 충돌 이후 치안의 안정화 및 질서 유지와 더불어 붕괴된 국가 제도와 사회적 가치의 복구를 위해서는 대규모 인적·물적 자원이 소요된다는 점에서 평화활동도 다차원적으로 변화되었다. 한편, 소말리아와 보스니아의 경우와 같이 분쟁 당사자 간 교전이 진행 중인 호전적인 상황에서 민간인 피해를 줄이고, 긴급 인도적 지원의 접근성이 확보되도록 지역 기구나 동맹국의 병력이 동원되어 전투 임무를 수행하는, 소위 평화강제(peace enforcement) 활동도 개시되었다.

이러한 다차원적 평화활동으로의 확대를 범주화하면 아래 <표 1>과 같다.

\section{〈표 1〉UN 평화활동의 범주화}

\begin{tabular}{|c|c|c|}
\hline Bellamy, Williams \& Griffin (2004) & Talentino (2004) & Diel, Druckman \& Wall (1998) \\
\hline $\begin{array}{l}\text { - 전통적 평화유지 활동 } \\
\text { - 과도정부 관리 활동 } \\
\text { - 확대된 평화유지 활동 } \\
\text { - 평화 강제 활동 } \\
\text { - 평화 지원 활동 }\end{array}$ & $\begin{array}{l}\text { • 제한적 활동 } \\
\text { - 확장적 활동 } \\
\text { - 국가 재건 활동 }\end{array}$ & $\begin{array}{l}\text { - 전통적 평화유지활동 } \\
\text { - 감시 활동 } \\
\text { - 집단적 강제 활동 } \\
\text { - 선거 감시 활동 } \\
\text { - 인도적 지원 활동 } \\
\text { - 국가 재건 활동 } \\
\text { - 치안·질서 유지 활동 } \\
\text { - 예방적 전개 활동 } \\
\text { - 무기 통제·검증 활동 } \\
\text { - 보호 서비스 지원 활동 } \\
\text { - 민주화 지원 활동 } \\
\text { - 제재 강행 활동 }\end{array}$ \\
\hline
\end{tabular}

출처: Diehl (1998: 13-15)을 참고해 저자가 재구성

이에 방법론적 측면에서 복잡한 양상을 띤 무력 충돌 전후에 대응하기 위해서는 군뿐만 아니라 민간 전문가(civilian experts)와 경찰 요원(UN Police)과 같이 분야별 역량을 보유한 행위자가 UN 임무단에 참여하게 되었다. 또한 임무단의 대표도 고위급 군 장성에서 민간 고위 관료인 사무총장 특별대표(Special Representative of the Secretary General)로 교체되었고, UN 국가팀의 조정관인 유엔개발계획(United Nations Development Programme, 이하 $\mathrm{UNDP}$ ) 지부장이 임무단 부대표를 겸임하면서 외부 행위자처럼 협력에 소극적이었던 UN기구 들이 평화활동의 방계형 거버넌스에 편입되었다. 아울러 기존의 파트너인 지역 기구와 더불어 
양자원조기구, 특히 INGOs을 비롯한 현지 시민사회 단체와의 협력이 부각되기 시작했다.

\section{UN 평화구축의 개념 형성과 진화}

UN 시스템 내에서 평화구축(peacebuilding)이라는 개념은 1992년 당시 부트로스 부트로스 -갈리(Boutros Boutros-Ghali) UN사무총장으로부터 제시되었다. 그는 『평화를 위한 아젠다 (An Agenda for Peace) 보고서』(이후 Agenda for Peace 보고서)를 통해 '평화를 강화하고 확고히 하는 구조를 규정하고 지원해 분쟁으로의 회귀를 막는 행위'로 정의했다(UN, 1992). 『Agenda for Peace 보고서』가 내포하는 특징은 목표에 있어 분쟁 재발의 방지, 목표 달성을 위한 계획된 전략과 활동의 수반, 시점상 $\mathrm{UN}$ 자체의 한계성으로 인해 최소주의적 관점에서 분쟁 후를 상정한다는 것이다(Diehl, 1998: 22-23). 따라서 부트로스-갈리의 보고서가 분쟁 후 평화구축(post-conflict peacebuilding)이라는 제한적인 개념을 표명했다면 평화 학계에서는 보다 적극적인 관점에서 평화구축의 담론을 형성했다.2)

한편, 개발협력의 관점에서 $\mathrm{UNDP}$ 는 무력 충돌로 회귀하는 위험을 경감시키는 것에는 맥을 같이 하나, 분쟁 관리를 위한 국가 역량 강화를 통해 지속 가능한 평화와 개발의 토대를 구축하는 데 방점을 두고 있다.3) 그리고 평화구축은 폭력의 구조적인 근인(根因)의 환기를 통해 무력 충돌을 예방하는 활동이다(OECD, 2011: 60). 갈등 해결 전략으로서 지속 가능한 평화와 폭력의 불법성을 촉구하고, 분쟁을 평화적으로 관리하는 사회적 역량을 구축하며, 폭력을 촉발하게 하는 취약성을 경감시키는 활동을 강조하고 있다(OECD, 2011).

새천년개발목표(Millennium Development Goals, 이하 MDGs)의 출범 당시 평화의제가 포함되지 않았지만, UN 체제에서 평화구축에 대한 정책적인 논의가 별도로 이뤼졌다. 2000년 브라히미 보고서(Brahimi Report)에서는 평화구축을 재정의했는데, '평화의 토대를 재구성하되 전쟁 부재 이상의 기반을 구축할 수 있도록 하는 활동' 으로 개입 시점의 재조정이 구체적으로 이뤄졌고, 무력 충돌의 원인에 대해 정치적 활동(유엔 정무국: Department of Political Affairs, DPA)과 개발(UNDP)이 융합된 효과적인 접근을 주문했다(UN, 2000). 이어서 구체적인

2) 대표적으로 갈퉁(Galtung; 1976)은 평화란 평화유지활동 및 일시적 평화 조성과 달리 전쟁의 원인을 제거하고 대체재를 제공하는 자체적 구조를 형성하는 보다 근원적 평화구축 개념을 제시했다. 한편, 분쟁 후 평화구축이라는 시계열적 관점에서 탈피해 분쟁을 지속적이고 평화로운 관계로 전환시키는 데 필요한 일련의 과정과 단계를 포괄하는 개념을 제시하는 구성주의적 관점이 제시되었다(Lederach, 1997).

3) UNDP 홈페이지, "Conflict Prevention and Peacebuilding" posted on United Nations Development Programme website, available at http://www.undp.org/content/undp/en/home/ourwork/democraticgovernance-and-peacebuilding/conflict-prevention-and-peacebuilding/ (접속일: 2018.11.15.). 
평화구축활동에 있어 분쟁국의 필요를 환기시키고 또 지속적 평화(Sustaining Peace)와 개발로 이행되도록 관련 재원을 조성하며, 공여국을 포함한 회원국들 간 논의의 장을 마련하는 데 있어 촉매제 역할을 담당할 평화구축위원회(Peacebuilding Commission)가 2005년 총회와 안전보장이사회의 산하 자문기구로 설립된다(UN, 2005).

전술했던 제한적 평화구축에서 지속적 평화의 개념으로 전환되는 과정에 있어 2015년에 채택된 SDGs가 분수령이 되었으며, 이전의 파편화된 평화구축을 구성하는 개념과 전략들이 통합되는 결과를 가져왔다. 대표적으로, 평화구축의 요소로서 범주화된 민주적 거버넌스 및 인권과 정의, 사법적 질서유지를 포괄하는 법치의 개념이 16 번 목표로 수렴된 것이다(김수진, 2015; 곽재성·이성훈·홍문숙·윤지영·김수진·송수전·김은영·장아영·정원선·박진아, 2018). 대응적 UN 평화활동의 제도적인 발전을 견인한 코피 아난(Kofi Annan) 사무총장의 기조를 이은 안토니오 구테헤스(António Guterres) 현 사무총장은 총회 결의안 제262호와 안전보장 이사회 결의안 제2282호에 근거해 2018년 4월, 『평화구축과 지속적 평화 보고서(Report on Peacebuilding and Sustaining Peace)를 발표하며 예방외교(preventive diplomacy)의 중요성을 재인식하고, 분쟁 발발의 대응적인 차원에서 분쟁의 전 과정을 관통하는 총체적 방지 기제로서 평화구축을 대입시켰다(UN, 2018).

\section{3. 평화구축과 지속적 평화의제에서의 시민사회}

개발협력의 이해관계자 담론에 있어 NGOs를 포괄하는 시민사회가 초국적 연대를 통해 정부 주도의 다자간 협약에 하향식 의사 결정을 촉구하고 또 결의 과정에 있어서도 영향력이 점증함에 따라, 2000년대 들어 개발협력 체제의 주요 행위자이자 대화 파트너로 인정받게 되었다. 이는 다차원적인 평화구축활동의 제도화 과정에서 UN 역시 시민사회를 인정하고 포용하는 입장을 적극적으로 표명했다.4)

『Agenda for Peace 보고서』(UN, 1992: para 84)에서는 UN 시스템과 회원국 정부만으로 평화를 성취할 수 없음을 자각하고 시민사회를 비롯한 학계와 의회, 기업 등과 이해의 공유와 참여가 필요함을 기술했다. 이를 계기로 $\mathrm{UN}$ 의 평화활동에 있어 $\mathrm{NGOs}$ 및 시민사회 간 접점

4) 1950년에 채택된 UN총회 결의안 제337호는 소위 ‘평화를 위한 통합결의(Uniting for Peace)'의 실행 근거로서 평화 위협 시 안전보장이사회의 거부권 행사로 인해 대응 조치가 불가할 때 총회가 병력 사용을 포함한 집단적 조치를 권고하도록 허용하는 내용을 포함하고 있는데, 주로 냉전 기간 동안 안전보장이사회의 불능 시 총회가 대행하는 경우가 있었다. 냉전 이후, 안전보장이사회로 권한이 집중되면서 유명무실해진 가운데, 2003년 이라크전쟁 시 안전보장 이사회가 적기에 대응을 못 하자 시민사회 단체들은 평화를 위한 통합결의 발동을 강력하게 주장한 바 있다(Mani and Ponzio, 2018). 
(interface)과 조정의 공간이 형성되었고, 이후 브라히미 보고서의 집필 과정에서 시민사회 관계자들의 의견을 청취하는 수준에서 유사시 파견 가능한 전문가 풀을 구축하는 데 시민사회와의 협력을 권고했다. 또 임무단의 유휴장비 일부를 검증된 현지 시민사회에 기증하는 것을 허용했으며, 평화와 안보 증진을 위한 유용한 파트너로서 시민사회 및 NGOs와의 협력을 지속적으로 유지할 것을 주문했다(UN, 2000).

별도로 거론하지 않았지만, 평화유지와 평화구축, 재건 및 복구의 전 과정에서 민간인에 대한 인권 보호와 적극적인 인도적 지원을 강조했다(UN, 2006). 이는 동 분야에서 오랫동안 활동해 왔던 시민사회의 참여가 요구된다는 것을 간접적으로 암시하고 있으며, 이는 UN평화임무단의 파병 전 민간인 보호 관련 교육 프로그램에도 시민사회의 역량과 협력의 필요성이 주요하게 반영되어 있었다.5)

2015년 SDGs의 출범을 계기로 평화구축에서 지속적 평화의제로 전환되면서 시민사회에 대한 중요성이 한층 강조되었다. SDGs의 도출 이전에는 평화활동에 있어 시민사회에 대한 인지 제고와 더불어 다소 선택적인 협력의 맥락이었다면, 이후에는 보다 구체적이고 실제적인 인식과 협력을 주문하고 있다. 『평화활동에 대한 고위급 독립패널 보고서(High Level Independent Panel on Peace Operations)에 의하면, “미래를 조망 시 시민사회의 부상과 민중의 목소리가 전 세계 민주주의와 인권의 확산을 위한 강력한 계기를 마련할 것(UN, 2015)"으로 기대하고 있다. 또 협력의 대상도 시민사회 단체를 비롯해 종교 단체, 여성과 청소년 단체들로 확대하고 이들의 활동을 적극 지지할 것을 확인했다(UN, 2015). 이러한 기조는 『평화구축과 지속적 평화 보고서를 통해 파트너들과의 새로운 플랫폼과 프레임워크를 제시함으로써 수사적 선언 이상의 의지를 재확인했다는 점에서 의의가 있다.6)

이와 같이 UN의 평화의제는 무력 충돌에 대한 대응적 평화기제에 오랫동안 천착해 오다가 재발 방지라는 제한적 개념의 평화구축을 제시하면서, 평화를 무력 충돌의 전개에 대한 선형적

5) 필자가 2011년 국방대학교 국제평화활동센터(KNDU PKO Center)의 요청으로 '민간인 보호(Protection of Civilians)' 교과를 개발 시 기초자료로 제공된 UN 자료를 보면, NGOs의 지위와 역할, 협조의 필요성에 대한 내용이 자세하게 설명되어 있다.

6) 안토니오 구테헤스 UN사무총장은 '평화네트워크를 위한 기업글로벌 컴팩트(the UN Global Compact's Business for Peace Network)', '평화와 안보 파트너십 촉진을 위한 UN과 아프리카연맹 간 공동 프레임워크(the Joint UN-African Union Framework for Enhanced Partnership in Peace and Security)', 'UN평화활동국의 신 지역사회 참여 프레임워크(UN DPKO's New Community-Engagement Framework)' 등을 제시하며 이해관계 자들과의 협력이 립서비스가 아님을 증명하고자 노력했다(Ponzio, 2018). 
사고에서 비선형적 개념의 틀로 점차 전환했으며, 필요 시 적시 개입이라는 예방적 접근을 강조하기에 이르렀다. 물론 MDGs에서 SDGs로의 전환이 주요한 계기를 마련했고, 이 과정에서 NGOs를 포함한 시민사회가 주요 이해관계자이자 변혁의 촉매제로서 유의미한 역할을 담당 했다고 볼 수 있다. 


\section{III. 평화구축 프로세스에 기초한 시민사회의 역할과 쟁점}

비국제적 무력 충돌이 빈번해진 1990년대 중반 이후, 평화구축을 위한 전환 과정에 있어 시민사회의 참여가 증대되는 양상을 볼 수 있다. 더구나 북구의 시민사회, 특히 인도적 지원과 개발협력에 전문성을 보유한 북구의 대형 INGOs 중 세이브더칠드런(Save the Children), 케어 (CARE), 옥스팜(Oxfam), 월드비전(World Vision), 국경없는의사회(Médecins Sans Frontières, $\mathrm{MSF}$ ) 등이 무력 충돌의 과정에서 설립되었고, 이들의 활동 영역이 초기 인도적 지원에서 1970년대 에는 지역개발이 주요 임무로 편입되었다. 또한 1990년대 들어서는 분쟁국 내 시민사회의 형성과 화해, 옹호와 같은 평화구축의 과업까지 확대되고 있다(Gerstbauer, 2010: 849).

평화구축의 보편적인 정의가 부재한 만큼 복합적 위기 상황의 발생 가능성이 상존하는 환경 에서 현장의 정황적 맥락에 따라 활동의 범주도 다양해지고, 공공 영역과 민간 영역의 모호성도 배제할 수 없다. 또한 책임과 의무, 위계에 의한 의사 결정 체계가 규정된 공공 섹터와 달리 비정치성과 자율성, 독립성의 가치를 내포하는 시민사회가 갖는 유연성은 비정형적인 상황에서 긍정적인 측면을 부인할 수 없다(Aall, 1996; Natsios, 1997; Wehr, 1996).

이에 평화구축 프로세스에서 요구되는 영역에 대해 먼저 살펴보고, 해당 과업에서 INGOs를 중심으로 한 사례를 주로 점검하면서 시민사회의 역할을 살펴본 후, 시민사회의 참여에 따라 제기되고 있는 쟁점을 분석해 보고자 한다.

\section{1. 평화구축활동의 영역}

$\mathrm{UN}$ 내 평화구축활동은 대체로 안정기, 과도기, 통합기로 나눌 수 있다. 그러나 각 시기가 명확히 구분되기보다 중복과 회기가 가능한 유동성을 내포하고 있다(De Coning, 2005: 92). 또한 분쟁 당사국에서 배치되어 활동하는 UN임무단 및 국가팀은 활동 지역의 상황이나 안보리의 위임 명령(mandate)에 따라 상이한 과업을 수행할 수 있지만, 공통적으로 범주화할 수 있는 5 가지 분야를 추출한다면 '안보, 정치적 전환.거버넌스민주화, 사회경제적 개발, 인권-정의화해, 조정-관리-자원 동원으로 세분화할 수 있다(NEPAD, 2005). 한편, 본부 단위에서 평화 구축기금(Peacebuilding Fund)의 심의와 배분을 결정하는 평화구축위원회는 대응과 함께 예방적 성격을 내포하는 4가지 우선순위 영역을 정의하고 있다. 구체적으로 '(1) 평화 프로세스에 대한 임박한 위협과 평화협약 및 정치적 대화를 지원하는 이니셔티브에 대응하는 것, (2) 분쟁의 평화적 해결과 공존을 증진하기 위한 국가 역량의 구축과 강화, (3) 경제력 활성화, (4) 필수 
공공행정 서비스의 복구'로 구분된다(UN, 2005).

이라크와 아프가니스탄의 사례와 같이 안전보장이사회의 결의와 무관한 동맹국이 주도해 일으킨 무력 충돌 이후 수행된 재건과 안정화 작전의 일부가 평화구축활동으로 간주될 수 있다. 이라크 재건의 사례를 보면, 미국 주도의 동맹국이 추구했던 핵심 영역으로 5 가지를 제시했다. 그것은 거버넌스, 법치와 사법 분야의 조정, 경제 복구, 필수공공시설의 재건과 기타 개발사업의 조정, 공공외교다(Kwon 2011:145).7) UN의 평화구축활동과 비교되는 건 역시 공공외교의 영역으로, 현지 치안 상황에 대한 방어적 조치이자 자국의 우호적인 이미지를 지역사회에 확산 한다는 점에서 대비가 된다.

한편, UN기구 중 평화구축을 주요 임무 중 하나로 설정한 UNDP는 SDGs 16번을 단일 목표로 간주할 뿐만 아니라 17 개 목표를 성취하는 핵심요소로 보고 관련 사업을 8 개의 영역으로 구분해 추진하고 있다. 구체적인 방안으로 '갈등 예방, 포용적 정치 프로세스, 호응적이고 책무성 있는 제도 구현, 법치·정의·치안·인권, 청소년의 권익 강화, 부패 방지, 폭력적 극단주의 예방, $\mathrm{HIV}$ 및 보건'을 상정했다.8)

전술한 영역들을 다시 범주화하면, (1) 정치와 제도적 영역으로 포용적이면서 민주적 원칙들이 적용되고 제 기능을 할 수 있는 거버넌스 체계를 구축하는 것, (2) 포괄적인 법치의 영역으로 인권이 보호되고 공정한 사법 집행이 가능한 환경을 구축하는 것, (3) 안보의 영역에서 분쟁 당사자들의 해체와 재통합 그리고 치안과 안보를 담당하는 기구들을 총체적으로 재편하는 것, (4) 사회적 영역에서 난민과 국내 실향민의 안전한 귀환은 물론 여성과 아동 등 취약 계층에 대한 지원 체계 그리고 공공서비스 기능의 회복을 들 수 있다. 마지막으로 전시경제에서 정상적인 시장경제가 작동하도록 거시·미시경제를 활성화해 평화의 배당(peace dividend)을 분배할 수 있는 시스템을 구축하는 경제 영역이다. 또한 전술한 평화구축활동의 시기별로 요구되는 활동들을 분류해 본다면, 단기적으로는 갈등과 위기 관리를 통해 분쟁 당사자 간 합의를 도출하는 것이 우선적으로 수행되어야 하고, 중기에는 주로 사회·경제적 활성화와 물리적 시설의 복구가 요구되며, 장기적으로 현지 지역사회의 반목적 태도와 행위, 무기력함의 변화를 추구해 폭력적 갈등 상황으로의 회귀를 차단해야 한다(Peinado, 2003).

7) 비 UN 평화활동의 경우, 안전보장이사회의 결의 없이 수행되었고, 대테러 활동의 일환이기 때문에 대의명분이 부재하다는 점에서 문제점이 제기될 수 있다. 하지만 정치·사회·경제적 제도의 복구가 주요 목표이고, 시민사회를 포함한 다양한 행위체가 참여한다는 측면에서 검토할 필요가 있다.

8) UNDP 홈페이지, “Democratic Governance and Peacebuilding” posted on United Nations Development Programme website, available at http://www.undp.org/content/undp/en/home/democratic-governanceand-peacebuilding.html (접속일: 2018.11.16.). 


\section{2. 평화구축 프로세스에서 시민사회의 역할}

평화구축에 있어 시민사회는 인도적 지원과 개발을 주요 임무(mandate)로 하는 NGOs를 포함해 다양한 행위자를 포괄해야 한다는 전제를 언급한 바 있다.9) 1990년대 초에는 주로 북구의 시민사회를 중심으로 무력 충돌 이후 지역사회의 재건·복구 임무와 더불어 선결 요건인 복합적인 사회적 갈등 문제의 해결을 포함한 평화구축에 대한 외부적 요구, 즉 공여기구의 필요와 재원이 결부되어 참여가 확대되었다. 그러나 1990년대 중반부터는 현지 시민사회가 주도하는 평화구축의 적법성과 유용성이 크다는 학계와 북구 시민사회의 인식이 확산되면서 평화구축활동도 국제적·국가적·지역사회 등의 다양한 층위에서 추진되고, 특히 현지 시민사회를 지원하는 형태가 주류를 형성하게 되었다(Paffenholz, 2009: 65).

평화구축에 있어 시민사회의 역할은 주로 민주화와 거버넌스에서 요구되는 임무에 기인하는데, 파펜홀츠와 스펄크(Paffenholz and Spurk, 2006)는 선행연구를 통해 7가지 역할을 제시했다.

첫째, 보호 활동으로서 이는 시민사회가 다른 역할과 기능을 수행하는 데 있어서도 선결 요건이라고 할 수 있다. 평화구축에 있어 전제적 정부뿐만 아니라 무장 그룹은 시민사회와 더불어 민간인에 대해서도 중대한 위협이 될 수 있다. 이런 점으로 볼 때 보호를 답보하기 위해서는 외부 시민사회, 즉 인권과 옹호 등의 임무를 수행하는 INGOs들과의 협력과 연대가 중요하고(Orjuela 2004: 47), 이를 토대로 인간안보(human security)와 같은 이니셔티브나 무장 행위가 허용되지 않는 평화구역(peace-zone)의 설정 등이 주효한 활동이 될 수 있다. 또한 물리적인 폭력의 방지라는 측면에서 평화유지군이나 UN경찰과 같은 공공 행위자의 보호 역할도 일부 요구된다.

둘째, 감시 및 책무성 기반의 활동이다. 감시는 보호와 옹호 활동의 주요 기제이면서도 정부가 민주화와 거버넌스 체계 구축에 책무성을 갖도록 하는 영향력 있는 압력으로 작용한다. 또한 효과적인 감시는 무력 충돌의 발생이나 회기에 대한 조기 경보의 기능을 한다는 측면에서 유효한 활동이다. 마찬가지로, 현지 시민사회와 외부 시민사회의 협력이 중요하다. 주요 사례로, 네팔의 인권 단체들이 현지 지역사회와 조력하면서 국제사면기구(Amnesty International)와 긴밀한 네트워크를 구축해 조직적인 인권 침해를 감시하는 역할을 담당했다.

셋째, 대중 커뮤니케이션을 토대로 한 옹호 활동으로, 평화구축의 맥락에서 지역사회의 중요한

9) 물론 이러한 포괄성은 다양한 섹터 간 경계가 모호해지고, 상이한 목적의 시민사회 행위자의 목적과 역할 그리고 목표에 대해 제대로 규정하기 어렵다는 단점을 안고 있다(Paffenholz, 2009: 65). 다만, 활동과 수단에 있어 정당화될 수 없는 폭력과 같은 소위 비시민적(uncivil) 행위를 하는 단체는 예외로 한다. 
평화 이슈를 국가 차원으로 의제화하는 데 있어서 매개 역할을 담당한다는 차원에서 현지 시민사회의 중요성이 부각된다. 한편, 외부 시민사회는 분쟁 당사국의 이슈를 국제사회에서 인식하게 한다는 측면에서 역시 유효하다. 중요한 건, 옹호 활동은 무력 충돌의 전 과정에 걸쳐 수행되어야 한다는 것이다. 무력 충돌의 소강 상태에서 분쟁 당사자들이 평화를 위한 대화 채널로 나오도록 대중을 조직화해 직간접적인 압력을 가하거나 평화 체제로의 전환 과정에서 공공 행위자 중심으로 전개되는 대화 체제에 시민사회가 참여할 수 있는 공간을 마련하는 것이다. 1990년대 초 스웨덴의 생명평화연구소(Sweden Life \& Peace Institute)는 소말리아 사태에 대해 사람 중심의 평화 프로세스, 즉 상향식 해결 방식의 접근에 있어 UN을 포함한 국제사회나 원조기구 조정회의체 및 각종 국제회의에서 호응을 받은 바 있다(Paffenholz, 2003: 56-57).

넷째, 내 그룹 사회화 활동으로 평화적 풍토를 조성하는 것이다. 이는 개인부터 지역사회에 이르기까지 평화적인 갈등 전환과 화해에 대한 긍정적 태도를 견지하도록 지원함으로써 민주화와 수평적 거버넌스를 확고히 하는 것이라고 할 수 있다. 현지 시민사회는 평화적 공존을 위한 내 그룹의 태도적 변화와 결집을 강화하는 데 주력하는 한편, 외부 시민사회는 미디어를 활용한 평화 교육과 갈등 해결 혹은 교섭에 대한 연수를 함으로써 보완이 가능하다. 이를테면, 제네바에 기반한 국제분쟁사회사업(International War-torn Society Project)은 이스라엘과 팔레스타인 각 그룹의 평화적 노력과 이해에 대한 인식의 제고에 먼저 착수했다.

다섯째, 갈등에 민감한 사회적 응집력 증진 활동이다. 내 그룹 사회화가 동일 집단 내 활동이라면 사회적 응집력 강화는 이전 혹은 현재 반목적 위치에 있는 집단 간의 화해와 협력에 방점을 둔다고 할 수 있다. 이를 위해 서비스 제공 과정에서 이종의 반목 집단이 공동으로 기획하고 추진한다든지, 유사한 사회적 위치나 직종 간 연합 조직을 설립하거나 공동 문화행사 등을 주선하는 것이다. 인도의 경우, 다민족 사회에서 기업, 노동조합 혹은 기타 사회단체를 통한 공동의 활동이 폭력적 갈등을 통제하는 데 유효했다고 밝혀진 바 있다(Varshney, 2002: 46).

여섯째, 평화구축 과정에서 정부와 시민 간의 관계를 포함한 다양한 이해관계자의 층위에서 요구되는 중재의 역할이다. 물론 정부 간 혹은 정부와 무장 그룹 간 중재와 같은 공식적 중재에서 시민사회의 역할이 제한되기도 하지만, 하위 지역 단위에서는 그러한 역할이 요구된다. 여기에는 지역에 연고를 두고 있는 무장 그룹 간, 무장 그룹과 지역사회 간, 무장 그룹과 인도적 지원기구 간 등 공식적·비공식적 중재도 포함된다. 실례로, 엘살바도르의 내전 기간 동안 교회 단체들이 아동을 대상으로 한 백신 캠페인을 전개하고, 평화 구역 혹은 무력 사용 금지 기간을 설정하기 위해 분쟁 당사자 간 중재에 참여해 이를 관철시킨 바 있다(Kurtenbach and Paffenholz, 1994). 
일곱째, 필수적 서비스의 공급 역할이다. 물론 이 역할이 기본적으로 정부나 기업의 기능이라는 점에서 시민사회의 본원적 역할에 포함될 수 없다는 주장도 있다. 그러나 무력 충돌로 인한 정부와 시장 기능이 부재한 상황에서 인간의 생존에 직결되는 문제인 만큼 시민사회에 있어 또 하나의 분리된 역할이라는 주장도 설득력을 얻고 있다(Barnes, 2005). 특히 시민사회의 지원 서비스 역할은 현지 평화구축활동의 진입에 용이한 진입 기제로 활용될 수 있다는 점에서 공여 기구들도 관심을 갖는 부분이다(Anderson, 1999). 또한 스리랑카의 북부에서 정부군과 무장 그룹, 타밀엘람 해방 호랑이(Liberation Tigers of Tamil Eelam, LTTE) 간 휴전 직후에 착수된 긴급 교육 서비스 사업은 이전에 대화 채널이 부재한 분쟁 당사자들이 참여하는 구 단위 사업위원회를 형성하는 계기를 제공했다(Paffenholz, 2003).

〈표 2〉시민사회의 평화구축활동 비교

\begin{tabular}{l|l|l}
\hline \multicolumn{1}{c|}{ 시민사회의 역할 } & \multicolumn{1}{|c}{ 활동 내용 } & \multicolumn{1}{c}{ 추진 시점 } \\
\hline 보호 활동 & 모든 무력 행위자로부터 보호 & 무력 충돌 중 \\
\hline 감시 및 책무성 기반 활동 & $\begin{array}{l}\text { 인권 관련 정부 및 무장 그룹의 감시와 조기 } \\
\text { 경보 연계 활력 충돌 중 / 보호 및 } \\
\text { 옹호와 연계 시 효과 }\end{array}$ \\
\hline $\begin{array}{l}\text { 대중 커뮤니케이션 기반 옹호 } \\
\text { 활동 }\end{array}$ & $\begin{array}{l}\text { 지역의 이슈를 국가적 의제화로 연계하고, } \\
\text { 평화 절차에 참여 기반 마련 }\end{array}$ & 무력 충돌의 전 과정 \\
\hline 내 그룹 사회화 활동 & $\begin{array}{l}\text { 평화적 풍토와 화해에 대한 내 그룹 태도의 } \\
\text { 변화 유도 및 촉구 }\end{array}$ & 무력 충돌 이후 \\
\hline 갈등 반영 사회적 응집력 증진 & 반목 그룹 간 접점과 교류 기반 마련 & 무력 충돌 중에도 가능하나 \\
활동 & 이후에 유효 \\
\hline 중재 활동 & $\begin{array}{l}\text { 정부와 시민을 포함한 다양한 분쟁 당사자와 } \\
\text { 이해관계자 간 교섭 }\end{array}$ & 무력 충돌 중이나 이후 \\
\hline 필수적 서비스 제공 활동 & $\begin{array}{l}\text { 이해관계자가 모두 공감하는 서비스 제공을 } \\
\text { 교두보로 삼아 평화구축으로 진전 }\end{array}$ & 무력 충돌 이후 \\
\hline
\end{tabular}

출처: Paffenholz and Spurk (2006), p.32를 참고해 저자가 재구성

\section{3. 주요 쟁점}

평화구축의 맥락에서 볼 때, 시민사회는 평화를 통한 안정화의 중요한 행위자이자 무력 충돌에서 평화구축으로 전환하는 데 있어 촉매제 역할을 한다. 한편, 평화활동과 평화구축이 이행되는 현장 에서 NGOs를 포함한 시민사회의 개입에 대해 우려와 비판적인 입장도 감지되고 있다.

첫째, 분쟁 당사국 및 지역사회의 맥락과 내재된 이해관계의 심도 있는 이해와 경험이 부족한 외부 시민사회, 즉 서구 시민사회의 개입으로 발생하는 오류다. 폴러니(Pouligny, 2005)는 
외부자들은 현지 시민사회의 복잡한 다양성을 간과함으로써 현지인들을 지원하고 또 권한을 강화하는 프로그램에 실제 역효과를 가져올 수 있는 현장의 문제점을 제기했다. 특히, 서구적 관점에 기인한 시민사회의 개념이 현지 지역사회에 부재하거나 맥락에 부합하지 않을 경우, 파급효과는 제한적일 수밖에 없다.

둘째, 평화구축의 단기와 중-장기 목적의 불일치 혹은 비대칭의 문제로 인해 주로 서비스 기반의 NGOs 활동에서 제기되는 쟁점이다. 전술한 대로 시민사회에 요구되는 역할은 다분히 복합적이고 또 상호 연계되어 있을 뿐만 아니라 최소 5년에서 10년 이상의 중·장기적인 목표를 토대로 수행되어야 한다는 점에서 자원뿐만 아니라 의지도 중요하다. 서비스 기반의 NGOs는 공여 기구의 목적과 재원 확보라는 외부적 요인에 민감하다 보니 현지의 실제적인 요구보다 자체적인 역량과 공여 기구의 의도에 중점을 두는 경향이 있고, 평화구축에 있어 중·장기 서비스 공급이 때로 분쟁을 예방하기보다 불공정하고 또 전시경제를 연명하게 하는 수단으로 전락할 수 있다는 것을 경고하고 있다(Carey, 2003).

셋째, 평화구축 과정에서 생성된 현지의 시민사회, 특히 도시를 중심으로 활동하는 시민사회 단체의 대표성과 편중된 자원의 문제다. 이들의 회원 기반이 제한적일 경우에는 전국적인 네트 워크 구축이 어렵고, 다민족 국가의 맥락에서 볼 때 민족별 구성도 현안이 될 수 있으며 또 정치계와 시민사회계의 구분이 모호한 사회에서는 시민사회의 구성원이 정치적 결사체와 암묵적 으로 연계할 수도 있다. 이러한 현지 시민단체는 지역사회보다 주로 재원이 제공되는 외부의 시민사회에 대한 책무성에 천착할 가능성을 배제할 수 없다는 점에서 지역사회의 사회적 자본 형성과 평화 절차에서의 주인 의식을 형성하는 데 한계가 있다. 그러므로 궁극적으로 볼 때 내부 동력의 약화와 종속적 위치에 머무르게 하는 동인이 된다(Belloni, 2001). 


\section{IV. 한국 시민사회의 활동 현황과 과제}

1980년대 중반, 한국의 시민사회는 재편을 통해 민주주의를 견인하면서 ‘동원적 시민사회’를 형성했고, 민주화 정부 이후에는 급속한 양적 성장과 질적 발전을 통해 '제도적 시민사회’를 창출했다(임혁백, 2009). 한국 시민사회의 한 축인 개발협력계의 시민사회는 이보다 늦은 1990 년대 초, 한국 정부가 공적개발원조(Official Development Assistance, 이하 ODA)에 본격적 으로 착수했던 것과 맥을 같이하며 제도화가 진행되었다.10) 이로써 빈곤·보건·교육·인권 등 초국적인 이슈들, 불공정한 글로벌 공공재의 분배와 남용에 대한 대안적 행동을 통해 대중으로 부터 활동의 정당성을 인정받았다. 또한 개발협력의 인력 생태계에서 양질의 인력이 지속적으로 유입되어 직종의 전문화가 일정 부분 이뤄졌으며, 공적 재원인 $\mathrm{ODA}$ 이외에 개인 모금과 기업의 후원을 포함한 개발 재원이 증대되면서 시장화가 동시에 이뤼졌다(양동휘, 2015). 그러나 개발 협력 시민사회의 양적인 성장 이면에 인적·물적 자원 등 규모적인 측면의 양극화가 현안으로 대두되었고(손혁상·신재은.이주희, 2011), 시민사회의 내외부에 걸쳐 질적 제도화에 대한 문제 제기도 지속되고 있다.

한국의 민주화와 사회적 가치에 천착했던 주류 시민사회와 달리 개발협력 시민사회는 주로 교육과 보건, 인프라 등 개발도상국 내 사회경제적 서비스 제공 분야에 집중해 왔다. 반면, 탈정치적 입장을 견지함으로써 현안에 따라 개발도상국 현지 정부와 긴장 관계 형성이 불가피한 분야, 즉 SDG16에서 제시하는 평화와 인권, 포용적 제도에 대해서는 개입을 최소화하는 경향을 보여 준다. SDG16 목표 중 평화에 직접 해당하는 '분쟁, 평화, 치안' 분야의 사업 현황을 보면, 2013년도에 1건과 2015년에 2건으로 나타났다. 이때 사업비는 각각 3천4백만 원과 9천6백만 원으로 $0.1 \%$ 에 해당하며, 평화구축의 도입 기제로 간주될 수 있는 긴급 구호와 재건 구호는 2015년도 기준 176 건으로 $8.1 \%$ 이고, 사업비는 114 억 원으로 $23.5 \%$ 에 해당된다(KCOC, 2016). 이는 한국국제협력단(Korea International Cooperation Agency, 이하 KOICA)의 경우도 크게 다르지 않다. 2017년부터 2018년 1분기까지 총 5분기에 걸친 SDG16 목표의 사업 현황 분석을 볼 때 평화와 관련된 사업은 총 13 건인데 비해 인권은 17 건, 민주적 거버넌스는 85 건으로 나타나 평화 부문에 대한 관심과 재원이 충분치 않음을 보여 주고 있다(곽재성 외., 2018: 140-148).

10) 2016년 기준, 개발협력 시민사회의 협의체인 국제개발협력민간협의회(Korea NGO Council for Overseas Development Cooperation, 이하 KCOC)의 회원 단체가 총 127 개이고, 상근 및 비상근 인력을 포함해 9,600여 명이 근무하고 있으며, 총 모금액 1 조 8 천억 원 중 5,227 억 원이 개발협력사업에 투입되었다(KCOC 홈페이지, http://www.ngokcoc.or.kr/theme/kcoc/03/society04.php)(접속일: 2018.11.19.). 
한편, $\mathrm{KOICA}$ 는 올 2 월에 발표한 10 대 혁신 중점과제 중 제 3 번 과제로 '평화, 인권, 민주주의 성 평등 등 보편적 가치 실현에 기여’를 선정함으로써 한국 개발협력계의 평화구축과 지속적인 평화의 의제화를 선점했다. 그리고 이행 방안에 따른 연구를 수행해 'SDG16의 대상화 이행 강화 방안’과 'SDGs 주류화 이행 강화 방안'을 마련했고, 이행 전략 중 하나로 시민사회와의 연대를 제시했다(곽재성 외., 2018).

이는 분명히, 개발협력 시민사회에는 도전적인 상황이다. 우선, 시민사회운동의 존재론적 가치로 여겨지는 평화와 민주화의 담론이 공공기관에 의해 먼저 주창되고 의제화되었다는 사실은 개발협력 시민사회에 경종을 울리고 있다. SDG16 목표가 자체 이행의 범위를 넘어 연관 목표들을 아우르는 광범위한 개념으로 재해석되어야 한다는 점에서 향후 유관 분야의 민관 협력 파트너십과 더불어 프로그램형 사업으로 확대될 경우, 개발협력 시민사회가 차지하고 있는 선도적 지위만 으로 참여하기에는 어려울 것으로 보인다. 한편 평화와 인권, 민주화와 거버넌스 분야에서 활동했던 시민사회에는 한국에서 민주적 제도화에 기여한 지식과 경험을 개발도상국 시민사회와 연대를 통해 공유하고 발전시킴으로써 초국적 시민사회 네트워크 기반을 구축하는 기회가 될 것으로 보인다. 실제, 서구 공여국의 경우에는 개발협력 분야에 다양한 층위의 시민사회 단체가 참여하고 있으며, 공여 기관도 서비스 공여 이외에 협력국의 민주화 이행에 기여할 수 있는 민간 단체들과 유연한 파트너십을 형성하고 있다. 다만, 개발협력의 지식과 현지 지역사회의 경험들이 단기간에 습득하기 어렵다는 점은 진입 장벽으로 작용할 것이다.

이러한 위기와 기회가 공존하는 가운데 한국의 시민사회가 SDG16과 연계된 평화구축과 지속적 평화의제에 참여를 확대하는 방안은 무엇일까? 먼저, 개발협력 시민사회 단체와 평화. 인권·민주화에 기반한 시민사회 단체 간 SDG16의 이행을 위한 연대를 구축하는 것이다. 이는 '한국 시민사회 SDGs 네트워크' 혹은 '국제개발협력 시민사회포럼(Korea Civil Society Forum on International Development Cooperation, $\mathrm{KoFID}$ )'과 같이 기존 협의체가 역할을 담당하거나 독자적인 네트워크를 만들 수도 있을 것이다. 이 연대는 KOICA가 설정한 평화의제의 이행 방안에 대한 비판적인 시각에서 시민사회 차원의 비전과 목표를 설정하는 역할과 더불어 $\mathrm{SDG} 16$ 의 이행에 대한 감시와 건설적인 정책 대안을 제시할 수 있어야 한다.

둘째, 분쟁·취약국을 대상으로 평화구축사업을 수행할 수 있는 시민사회의 인식 제고와 인적 자원 및 역량의 개발이다. 먼저, 서구의 개발협력 시민사회 사례를 보면, 1990년대 당시 UN과 공여 기관 등 외부의 요구를 수용하고 내재화하는 데 그치지 않고 기존의 미션과 인식을 재정의 하는 데 노력을 기울였다. 그럼에도 불구하고 분쟁의 정황 해석 오류와 지역사회 갈등의 몰이해, 전통적 개발 방식의 접근은 개입에 대한 영향력의 부재와 갈등의 악화라는 비판에 직면했다. 
한국의 시민사회가 이러한 전철을 밟지 않기 위해서는 기존 서비스 제공의 역량을 토대로 전술 했던 평화구축 관련 역량을 키워야 한다. 그러면 시행착오를 최소화하고 보다 긍정적인 성과를 거둘 수 있을 것으로 기대된다.

셋째, $\mathrm{KOICA}$ 는 SDG16과 연관된 프로그램이나 민관 협력 사업을 컨소시엄형으로 설계해 개발협력을 포함한 다양한 분야와 층위의 시민사회가 참여할 수 있는 여건을 마련해 줄 필요가 있다. 이와 관련해, 영국 국제개발부(Department for International Development, DFID)가 2017년부터 추진하고 있는 개발 컨소시엄 기금사업(UK Aid Connect)을 벤치마킹하는 것도 좋은 방법이 될 수 있다. 동 사업은 개발협력 주체의 컨소시엄을 통해 통합적 역량을 도모해 개발 문제와 관련된 창의적이고 혁신적인 접근을 유도할 목적으로 도입되었다. 시민사회 단체와 고등교육기관, 기업 등이 다양한 방식으로 제휴를 하는데, 최소 3 백만 파운드에서 9 백만 파운드 까지 지원해 주고 있다. 이와 더불어, 필요할 경우에는 민관 협력 플랫폼을 마련해 형성과 기획, 추진 과정에서 협업의 틀을 마련하는 것도 고려할 수 있다.

넷째, 분쟁·취약국의 평화구축을 위한 한국 시민사회의 역량과 초국적 네트워크의 힘이 한반도 평화 체제의 구축의 과정에서 궁극적으로 제기될 수 있는 재래 무기 군축 문제와 인권·인도적 지원 및 개발에 이르기까지 다양한 현안의 해결 방안 도출을 촉구하고, 남북 당국과 이해 당사국을 논의의 장에 유인한 후 협의하는 환경을 마련하는 데 기여할 필요가 있다. 


\section{V. 결론}

SDG16의 국내 이행과 관련해 촛불혁명의 정신을 계승한 현 정부는 금년 2월, 정부의 운영을 사회적 가치에 중심을 두는 전략을 최우선으로 삼았다. 이에 초점을 맞춰 인권·안전·환경· 사회적 약자 배려 등을 실현하는 사업에 재정투자를 확대하는 방안과 함께 국민 참여와 소통을 활성화하는 액션 플랜을 수립했다. 또한 4월 판문점선언과 9월 평양공동선언을 통해 한반도 비핵화에 대한 의지를 천명함으로써 종전선언과 평화협정으로 이어지는 한반도 평화로드맵을 제시하고 이행 중이다. 이러한 전향적인 변화의 과정에서 한국의 시민사회는 제도적 민주화와 한반도의 평화 이니셔티브의 결행에 따른 대중적 참여와 지지를 촉구하는 데 중요한 역할을 담당했다.

이제 SDG16의 실제적 이행이 절실한 분쟁·취약국을 대상으로 평화구축과 지속적 평화를 위해 한국 정부와 개발협력 시민사회를 포함한 다양한 분야의 시민사회가 연대를 구축해 적극적 으로 참여해야 할 시점이다. 특히, 개발협력 시민사회는 탈정치적인 입장에서 선회해 현장에 대한 지식과 경험으로 축적한 인도적 지원과 개발 경험을 토대로 평화구축 역량을 개발하고, 갈등 감수성을 반영한 사업을 형성할 필요가 있다. 또한 평화·인권·민주화에 기반한 시민사회는 개발협력 시민사회 혹은 개발도상국 시민사회와 파트너십을 구축해 분쟁·취약국의 지역 단위에서 균열되고, 반목적인 사회가 화해를 통해 응집력을 강화하고 민주적 거버넌스가 정착되는 데 기여할 수 있는 현지 시민사회를 육성하고 지원하는 데 참여할 수 있다.

아울러 한국 정부는 한국 시민사회와 전문가들이 참여하는 SDG16 이행 협의체를 마련해 가이드라인을 포함한 시민사회 차원의 구체적인 액션 플랜을 함께 수립할 필요가 있다. 또한 시민사회의 평화구축 역량을 개발하기 위한 지원과 함께 분쟁·취약국에서 활동할 수 있도록 제도적 지원이 요구된다. 특히, 제도적 차원에서 대상 국가들이 주로 적색경보나 흑색경보 지역에 편중되어 있어 접근에 대한 예외적 허용을 고려해야 할 것이다. 중요한 건, 평화구축사업에 참여하는 시민사회가 불안정한 치안 환경에서 활동할 경우에 필수적으로 요구되는 차량, 무전기, 안전가옥, 심리사회적 지원을 위한 주기적 휴가, 긴급후송계획 등의 안전 대책을 마련해야 할 것이다. 또 이를 적용하기 위한 예산을 자체적으로 마련하기 어려울 경우에는 공모 사업이나 민관 협력 사업에 한해 정부가 예산을 배정하고, 관련 비용을 인정하는 등 제반 조치가 필요하다. 


\section{〈참고 문헌〉}

곽재성·이성훈·홍문숙·윤지영·김수진·송수전·김은영·장아영·정원선·박진아. 2018. 『SDGs

16 달성을 위한 $\mathrm{KOICA}$ 이행방안 연구』. 성남: 한국국제협력단.

김수진. 2015. “Goal 16: 지속가능발전을 위한 평화롭고 포용적인 사회촉진, 사법접근성

확보, 모든 차원에서 효과적이고 신뢰할 수 있는 포용적인 제도 구축.” 『지속가능목표

(SDGs) 수립현황과 대응방안』. 성남: 한국국제협력단. pp.309-330.

임혁백. 2009. “민주화 이후 한국 시민사회의 부활과 지속적 발전.” 『OUGHTOPIA』

24(1): 137-169.

양동휘. 2015. “한국 국제개발NGO의 제도화 과정." 『한국사회학회 사회학대회 논문집』

2015년 한국사회학회 후기사회학대회 (2015.12.18-19, 서강대학교).

손혁상·신재은·이주희. 2011. 『한국 개발 $\mathrm{NGO}$ 역량현황 기초조사 및 역량강화 방안

연구』. 성남: 한국국제협력단.

KCOC. 2016. 『2015 한국 국제개발협력 CSO 편람』. 서울: 국제개발협력민간협의회.

Aall, Pamela. 1996. "Nongovernmental Organizations and Peacemaking.” pp.433443 in Managing Global Chaos Sources of and Responses to International Conflict, edited by Chester A. Crocker, Fen Osler Hampson, and Pamela Aall. Washington D.C.: United States Institute of Peace.

Anderson, Mary B. 1999. Do No Harm: How Aid Can Support Peace or War. Boulder: Lynne Rienner Publishers.

Barnes, Catherine. 2005. "Weaving the Web: Civil-Society Roles in Working with Conflict and Building Peace." pp.7-24 in People Building Peace II, Successful Stories of Civil Society, edited by Paul van Tongeren, Malin Brenk, Marte Hellema, and Juliette Verhoeven. Boulder: Lynne Rienner Publishers.

Bellamy, Alex J., Paul D. Williams, and Stuart Griffin. 2004. Understanding Peacekeeping. Cambridge: Polity Press.

Belloni, Roberto. 2001. "Civil Society and Peacebuilding in Bosnia and Herzegovina." Journal of Peace Research vol.38(2): 163-80.

Carey, Henry F. 2003. "Conclusion: Ngo Dilemmas in Peace Processes." International Peacekeeping vol.10(1): 172-179. 
Crocker, Chester A., Fen Osler Hampton, and Pamela All. 2001. Turbulent Peace: The Challenges of Managing International Conflicts. Washington D.C.: United States Institute of Peace Press.

De Coning, Cedric. 2005. "Civil-Military Coordination and UN Peacebuilding Operations." African Journal on Conflict Resolution vol.5(2): 89-118.

Diehl, Paul F. 1998. Peace Operations: War and Conflict in the Modern World. Cambridge: Polity Press.

Diehl, Paul F., Daniel Druckman, and James Wall. 1998. "International Peacekeeping and Conflict Resolution: A Taxonomic Analysis with Implication.” Journal of Conflict Resolution vol.42(1): 33-55.

Galtung, Johan. 1976. “Three Approaches to Peace: Peacekeeping, Peacemaking, and Peacebuilding." pp.282-304 in Peace, War and Defense: Essay in Peace Research, Volume II. Copenhagen: Christian Ejlers.

Gerstbauer, Loramy Conradi. 2010. "The Whole Story of NGO Mandate Change: The Peacebuilding Work of World Vision, Catholic Relief Services, and Mennonite Central Committee." Nonprofit and Voluntary Sector Quarterly vol.39(5): 844-865.

James, Alan. 1990. Peacekeeping in International Politics. London: MacMillan. Kurtenbach, Sabine, and Thania Paffenholz. 1994. "Kirchen können in Kriegen vermitteln.” Der Überblick vol.3(94): 16-119.

Kwon, Goo Soon. 2011. "Civil-Military Cooperation of the U.S.-led Post- conflict Reconstruction in Iraq: The Case Study of the Regional Reconstruction Team for Iraqi Kurdistan.” Ph.D. Dissertation, Korea University.

Lederach, John Paul. 1997. Building Peace: Sustainable Reconciliation in Divided Societies. Washington D.C.: United States Institute of Peace.

Mani, Rama, and Richard Ponzio. 2018. "Peaceful Settlement of Disputes and Conflict Prevention." In The Oxford Handbook on the United Nations, edited by Thomas G. Weiss and Sam Daws. New York: Oxford University Press, available at https://www.stimson.org/sites/default/files/Ch.\%2018Mani\%20\%20Ponzio.pdf (접속일: 2018.11.15.). 
Natsios, Andrew S. 1997. “An NGO perspective.” pp.337-361 in Peacemaking in International Conflict: Methods and Techniques, edited by I. William Zartman and J. Lewis Rasmussen. Washington D.C.: United States Institute of Peace.

NEPAD. 2005. "African Post-Conflict Reconstruction Policy Framework." Midrand: NEPAD Secretariat.

OCHA. 2018. “Annual Report 2017.” Geneva: United Nations Office for the Coordination of Humanitarian Affairs.

OECD. 2011. "International Engagement in Fragile States: Can We Do Better?." Paris: Organization for Economic Cooperation and Development.

Orjuela, Camilla. 2004. "Civil Society in Civil War, Peace Work and Identity Politics in Sri Lanka.” Ph.D. Dissertation, University of Göteborg.

Paffenholz, Thania. 2001. "Western Approaches to Mediation." pp.75-81 in Peacebuilding: A Field Guide, edited by Luc Reychler and Thania Paffenholz. Bouler: Lynne Rinner Publishers. 2003. "Community-based Bottom-up Peacebuilding." In

The Development of the Life and Peace Institute's Approach to Peacebuilding and Lessons Learned from the Somalia Experience (1990-2000). Uppsala: Life and Peace Institute.

2009. "Civil Society." pp.60-73 in Post-conflict Peacebuilding:

A Lexicon, edited by Vincent Chetail. Oxford: Oxford University Press. Paffenholz, Thania, and Christoph Spurk. 2006. "Civil Society, Civic Engagement, and Peacebuilding." Social Development Paper, no.100 and Conflict Prevention and Reconstruction Paper, no.36. Washington D.C.: World Bank. Peinado, Manuela M. 2003. "The Role of NGOs and the Civil Society in Peace and Reconciliation Process.” Madrid: Centro de Investigacion para la Paz. Ponzio, Richard. 2018. “The UN's new “Sustaining Peace” Agenda: A Policy Breakthrough in the Making” posted on Stimson Center website on 23 February, 2018, available at https://www.stimson.org/content/un-new -sustaining-peace-agenda-policy-breakthrough-making (접속일: 2018.11.15.). 
Pouligny, Béatrice. 2005. "Civil Society and Post-Conflict Peacebuilding: Ambiguities of International Programmes Aimed at Building 'New' Societies.” Security Dialogue vol.36(4): 495-510.

Reychler, Luc, and Thania Paffenholz (eds.). 2001. Peacebuilding: A Field Guide. Bouler: Lynne Rinner Publishers.

Suhrke, Astri, and Torunn Wimpelmann Chaudhary. 2009. "Conflict and Development." pp.406-424 in Introduction to International Development, edited by Paul Alexander Haslam, Jessica Schafer, and Pierre Beaudet. Ontario: Oxford University Press.

Talentino, Andrea Kathryn. 2004. “One Step Forward, One Step Back?: The Development of Peacebuilding as Concept and Strategy." Journal of Conflict Studies vol.25: 33-60.

UN. 1945. Charter of the United Nations. New York: United Nations.

_. 1992. “An Agenda for Peace, Preventive Diplomacy, Peacemaking and Peacekeeping." Report of the Secretary General Pursuant to the Statement Adopted the Summit Meeting of the Security Council on 31 January, 1992, A/47/277-S/24111, 17 June, 1992.

_. 2000. "Report of the Panel on United Nations Peace Operations" (Brahimi Report). General Assembly and Security Council, A/55/305-S/2000/809, 21 August 2000.

_. 2005. "The Peacebuilding Commission.” General Assembly, A/RES/60/180, 30 December, 2005.

. 2006. “Arrangement for Establishing the Peacebuilding Fund." Report of the Secretary General, General Assembly, A/60/984, 22 August, 2006.

. 2015. "Report of the High-level Independent Panel on Peace Operations on Uniting our Strengths for Peace: Politics, Partnership and People.” A/70/95-S/2015/446, 17 June 2015.

. 2018. "Peacebuilding and Sustaining Peace." Report of the Secretary General, A/72/707-S/2018/43, 18 January, 2018.

Varshney, Ashutosh. 2002. Ethnic Conflict and Civic Life: Hindus and Muslims in India. New Haven: Yale University Press. 
Wallensteen, P. 2017. "Wars, Civil Wars and Armed Conflict. Pattern, Trends and Analytic Paradigms." pp.253-271, in States and Peoples in Conflict: Transformations of Conflict Studies, edited by Michael Stohl, Mark I. Lichbach, and Peter Grabosky. London: Routledge.

Wehr, Paul. 1996. “The Citizen Intervenor.” Peace Review vol.8: 555-561.

$\mathrm{KCOC}$ 홈페이지. “한국 국제개발협력 $\mathrm{CSO}$ 활동현황.” 국제개발협력민간협의회(KCOC) 활동현황 안내 페이지. http://www.ngokcoc.or.kr/theme/kcoc/03/society04. php (접속일: 2018.11.19.).

UN Peacekeeping 홈페이지. “Our History” posted on United Nations Peacekeeping website, available at https://peacekeeping.un.org/en/ our-history (접속일: 2018.11.14.).

UNDP 홈페이지. "Conflict Prevention and Peacebuilding” posted on United Nations Development Programme website, available at http://www.undp.org/ content/undp/en/home/ourwork/democratic-governance-and-peacebuildin $\mathrm{g} /$ conflict-prevention-and-peacebuilding/ (접속일: 2018.11.15.).

"Democratic Governance and Peacebuilding" posted on United Nations Development Programme website, available at http://www.undp.org/ content/undp/en/home/democratic-governance-and-peacebuilding.html (접속일: 2018.11.16.). 